\title{
Susceptibility of Greenhouse Ornamentals to Phytophthora capsici and $P$. tropicalis
}

T. B. Enzenbacher, Former Graduate Research Assistant, R. P. Naegele, Postdoctoral Researcher, and M. K. Hausbeck, Professor, Department of Plant, Soil, and Microbial Sciences, Michigan State University, East Lansing 48824

\begin{abstract}
Enzenbacher, T. B., Naegele, R. P., and Hausbeck, M. K. 2015. Susceptibility of greenhouse ornamentals to Phytophthora capsici and P. tropicalis. Plant Dis. 99:1808-1815.

The susceptibility of fabaceous (Lupinus and Lathyrus spp.) and solanaceous (Calibrachoa, Browallia, Nicotiana, Nierembergia, and Petunia spp.) ornamental plants compared with straightneck squash (Cucurbita pepo) inoculated with Phytophthora capsici and P. tropicalis was investigated in greenhouse studies. Four $P$. capsici isolates and one $P$. tropicalis isolate were evaluated. Flowering tobacco (Nicotiana $\times$ sanderae), sweet pea (Lathyrus latifolius), lupine (Lupinus polyphyllus), squash, and million bells (Calibrachoa $\times$ hybrida) were susceptible to $P$. capsici and $P$. tropicalis. Bush violet (Browallia speciosa) and cup flower (Nierembergia scoparia) were not susceptible to either pathogen. Petunia (Petunia $\times$ hybrida) was susceptible to $P$. capsici but not $P$. tropicalis. Area under the plant growth curve (AUPGC) was also affected in some susceptible plants. AUPGC was significantly different in inoculated plants compared with

the untreated controls of Nicotiana and Calibrachoa. In addition, six Calibrachoa cultivars were evaluated for susceptibility to $P$. capsici and $P$. tropicalis in a separate experiment. Although all Calibrachoa cultivars were susceptible to $P$. capsici and P. tropicalis, 'Celebration Purple Star' displayed limited disease following inoculation with either pathogen. Calibrachoa 'Cabaret' and 'Can-Can' inoculated with $P$. capsici or $P$. tropicalis displayed significant differences in AUPGC compared with the uninoculated controls. 'Callie', 'Million Bells Cherry Pink', and 'Superbells' had significantly reduced AUPGC compared with the controls when inoculated with $P$. tropicalis but not $P$. capsici. These results expand the host range of $P$. capsici to include Calibrachoa spp., L. polyphyllus, and Lathyrus latifolius, and P. tropicalis to include L. latifolius, Nicotiana spp., and straightneck squash.
\end{abstract}

In 2013, floricultural sales in Michigan were approximately $\$ 406$ million, almost $10 \%$ of the United States total (\$4.4 billion) (USDA 2014). Michigan is ranked third in sales among the top five floricultural states in the United States for production of annuals, perennials, cut flowers, foliage plants, and propagative materials (USDA 2014). These ornamentals, grown entirely for aesthetic value, require diligent disease management (Baker and Linderman 1979). High humidity, warm temperatures, and moist conditions present in greenhouse and nursery environments are conducive to the growth, reproduction, and colonization of root rot pathogens. Greenhouse growers utilize a range of media, including packaged peat-based mixes and custom blends that incorporate a field soil component. Utilizing field soil for greenhouse-grown crops increases the potential for long-lived root rot pathogens such as Phytophthora spp. to enter the production system. Plants exhibiting aboveground root rot symptoms such as crown lesions, stunting, and wilting are not salable and result in financial losses to the grower (Baker and Linderman 1979).

Phytophthora tropicalis Aragaki \& J. Y. Uchida causes disease on numerous herbaceous ornamentals, including annual vinca (Catharanthus roseus) (Hao et al. 2010), cyclamen (Cyclamen persicum) (Gerlach and Schubert 2001), pothos (Epipremnum aureum), gloxinia (Sinningia speciosa), and verbena (Verbena $\times$ hybrida) (Olson and Benson 2011). Greenhouse studies have identified additional $P$. tropicalis-susceptible floriculture crops, including begonia (Begonia sp.), gerbera daisy (Gerbera jamesonii), lupine (Lupinus albus), and dusty miller (Senecio bicolor) (Hong et al. 2008). Greenhouse evaluations of important solanaceous ornamentals such as Petunia spp., and Calibrachoa spp. to P. tropicalis, have been limited (Ampuero et al. 2008; Omer et al. 2011). Calibrachoa is a relatively new genus to the ornamental industry because the first hybrids were

Corresponding author: M. K. Hausbeck; E-mail: hausbec1@msu.edu

Accepted for publication 14 May 2015.

http://dx.doi.org/10.1094/PDIS-03-15-0333-RE

(C) 2015 The American Phytopathological Society introduced in the early 1990 s with high economic importance (Schultz Nelson 2008). In 2007, Calibrachoa $\times$ hybrida Cerv. plants with crown and stem rot in a wholesale New York greenhouse were reported as being infected with $P$. capsici but the pathogen was later reidentified as $P$. tropicalis based on sequencing (Daughtrey and Tobiasz 2008; Quesada-Ocampo et al. 2011).

$P$. tropicalis was previously conspecific with $P$. capsici Leonian, and the two species share considerable morphological characteristics and host overlap (Alizadeh and Tsao 1985; Brasier and Griffin 1979; Lamour 2009; Uchida and Aragaki 1980). P. tropicalis was given a separate species taxon from $P$. capsici in 2001 based on the morphological characteristics, absence or minimal growth at $35^{\circ} \mathrm{C}$, and having weak or no pathogenicity on pepper (Capsicum annuum L.) (Aragaki and Uchida 2001; Leonian 1922). P. capsici is a major production limitation for susceptible vegetables in Michigan (Hausbeck and Lamour 2004), the United States (Babadoost 2000; Isakeit 2007; Mathis et al. 1999; Ploetz and Haynes 2000; Ristaino and Johnston 1999), and globally (Hwang and Kim 1995; Silvar et al. 2006) but has not been considered a major pathogen of ornamentals.

There is considerable host overlap between $P$. tropicalis and $P$. capsici, which may be due, in part, to difficulties in distinguishing the two species (Lamour 2009). Both cause disease on tropical species, including macadamia (Macadamia spp.), cacao (Theobroma cacao), eggplant (Solanum melongena L.) (Erwin and Ribeiro 1996), flamingo flower (Anthurium spp.), carnation (Dianthus spp.), pothos (Epipremnum spp.) (Orlikowski et al. 2006; Wick and Dicklow 2002), and pincushion flower (Leucospermum spp.) (Aragaki and Uchida 2001; Donahoo and Lamour 2008; Oudemans and Coffey 1991). Although P. capsici and P. tropicalis share common morphological characteristics and hosts, the presence of two distinct species is supported by genetic and phylogenetic analyses (Donahoo and Lamour 2008; Quesada-Ocampo et al. 2011; Zhang et al. 2004).

Historically, $P$. capsici has not been a problem on most ornamentals. However, many $P$. capsici-susceptible vegetable and weed hosts are members of the Fabaceae and Solanaceae families (Davidson et al. 2002; Erwin and Ribeiro 1996; Gevens et al. 2008; Hausbeck and Lamour 2004), which include important ornamentals such as 
L. polyphyllus, Lathyrus latifolius, and Petunia spp. The ornamental plants Lupinus polyphyllus and Calibrachoa spp. are known fabaceous and solanaceous hosts, respectively, of $P$. tropicalis (Daughtrey and Tobiasz 2008; Hong et al. 2008; Quesada-Ocampo et al. 2011). However, the susceptibility of economically important and common floriculture crops within these families to $P$. capsici has not been well investigated.

$P$. tropicalis and $P$. capsici are closely related taxa (Donahoo and Lamour 2008) infecting similar families, and the host range of both pathogens has continued to expand. Determining the susceptibility and symptoms of ornamental fabaceous and solanaceous plants to these two pathogens may provide important insight into strategies for effective disease management in greenhouse and field production of ornamentals and vegetables. The objectives of this research were to (i) investigate the etiology of $P$. capsici and $P$. tropicalis on economically important ornamental plants within the fabaceous and solanaceous families and (ii) compare the susceptibility and growth of Calibrachoa cultivars infected with these pathogens.

\section{Materials and Methods}

Isolate selection, identification, and maintenance. Four $P$. capsici isolates from the collection of Dr. Mary K. Hausbeck (Michigan State University [MSU]) and one $P$. tropicalis isolate from the collection of Dr. Margery Daughtrey (Cornell) were used as inocula. Isolates differed in phenotype (mating compatibility type [CT] and sensitivity to the fungicide mefenoxam [MS]) and host origin and were characterized by CT and MS, as described by Lamour and Hausbeck (2000). $P$. capsici isolates $\mathrm{OP} 97(\mathrm{CT}=\mathrm{A} 1, \mathrm{MS}=$ sensitive, host $=$ pickling cucumber), SP98 (A2, sensitive, pumpkin), and 12889 (A1, insensitive, pepper) have been shown to be highly virulent on various hosts (Enzenbacher and Hausbeck 2012; Foster and Hausbeck 2010; Quesada-Ocampo et al. 2009; Quesada-Ocampo and Hausbeck 2010). Isolates had been previously identified to species and characterized by sequencing (Quesada-Ocampo et al. 2011). P. capsici isolate 13351 (A1, sensitive, eggplant) was previously evaluated on eggplant and pepper (Foster et al. 2013). P. tropicalis isolate 13715 (A1, sensitive, Calibrachoa spp.) was previously reported as P. capsici (Daughtrey and Tobiasz 2008) but was reclassified as $P$. tropicalis following polymerase chain reaction (PCR) and sequencing of 10 genes (Quesada-Ocampo et al. 2011).

Isolates were obtained from long-term storage (microcentrifuge tubes containing $1 \mathrm{ml}$ of sterile water and 1 sterile hemp seed at $20^{\circ} \mathrm{C}$ ) and plated on unclarified V8 juice agar (UCV8; $16 \mathrm{~g}$ of agar, $3 \mathrm{~g}$ of calcium chloride $\left[\mathrm{CaCO}_{3}\right], 160 \mathrm{ml}$ of $\mathrm{V} 8$ juice, and $840 \mathrm{ml}$ of distilled water) amended with $0.50 \mathrm{~g}$ of benomyl, $2 \mathrm{ml}$ of ampicillin, and $2 \mathrm{ml}$ of rifampicin. Agar plugs $(5 \mathrm{~mm}$ in diameter) from 5- to 7-day-old cultures were used to inoculate straightneck squash (Cucurbita pepo) fruit prior to use in experiments to confirm pathogenicity. Five days postinoculation (dpi), symptomatic fruit tissue was excised and plated on BARP-amended UCV8 agar (12 $\mathrm{g}$ of agar, $0.3 \mathrm{~g}$ of $\mathrm{CaCO}_{3}, 40 \mathrm{ml}$ of $\mathrm{V} 8$ juice, $960 \mathrm{ml}$ of distilled water, $0.50 \mathrm{~g}$ of benomyl, $2 \mathrm{ml}$ of ampicillin, $2 \mathrm{ml}$ of rifampicin, and $0.10 \mathrm{~g}$ of pentachloronitrobenzene). Cultures were observed 3 days after plating using a compound microscope at $\times 100$ magnification to confirm $P$. capsici morphological characteristics according to Waterhouse (1963). P. tropicalis was confirmed according to Aragaki and Uchida (2001). Isolates were hyphal tipped and transferred to new UCV8 agar. Cultures were maintained at room temperature $\left(21\right.$ to $\left.23^{\circ} \mathrm{C}\right)$ under continuous fluorescent lighting and were transferred every 5 to 7 days to new UCV8 agar.

Pathogenicity on fabaceous and solanaceous plants. Seven ornamental species from two plant families were evaluated for their susceptibility to $P$. capsici and $P$. tropicalis compared with the $P$. capsici-susceptible control, squash (Table 1). The experimental design was a split-plot arrangement of a randomized complete block design, and the experiment was performed three times for disease incidence and two times for plant growth and volume. Runs 1 and 2 were performed in March 2010 at the MSU Horticulture Teaching and Research Center in Holt, MI, and run 3 was conducted in October 2010 at the MSU Plant Science Research Greenhouses in East Lansing, MI. Pathogen isolate and plant type were considered the whole-plot and subplot factors, respectively. Number of replicates differed among plant types and runs due to limited plant availability (Table 1).

Susceptibility to Phytophthora spp. among Calibrachoa cultivars. Six cultivars of Calibrachoa were evaluated for their susceptibility to P. capsici (isolate SP98) and P. tropicalis (isolate 13715) during February 2011. The experimental design was a split-plot arrangement of a randomized complete block design, and the experiment was performed twice. Runs were conducted in two separate greenhouse ranges at the MSU Plant Science Research Greenhouses (Table 1). Pathogen isolate and plant type were considered the whole-plot and subplot factors, respectively. There were 12 replicates of each cultivar for each isolate and the control.

Inoculation and evaluation. Rooted cuttings or seedlings were received from commercial producers (Table 1). Plant replicates were transplanted into individual $386.7-\mathrm{cm}^{3}$ pots containing soilless potting media (Baccto Professional Planting Mix; Michigan Peat Company, Houston) 14 days prior to inoculation. 'Cougar' straightneck squash seed (Rispens Seeds, Inc., Beecher, IL) were sown in a 128-cell plug tray filled with potting media 14 days prior to inoculation. Squash seedlings were transplanted into individual $386.7-\mathrm{cm}^{3}$ pots containing potting media 7 days prior to inoculation. Plants were watered as necessary and fertilized three times weekly at $200 \mathrm{ppm}$ with Peter's 20-20-20 soluble liquid fertilizer (The Scott's Company, Marysville, $\mathrm{OH})$. Plants were acid treated weekly with $10 \%$ phosphoric acid to maintain an appropriate $\mathrm{pH}$ in the growing media for the plants being tested. The Calibrachoa plugs grown for the cultivar susceptibility experiment were drenched with thiophanate-methyl (OHP 6672 4.5L; OHP, Inc., Mainland, PA) 2 days prior to transplanting

Table 1. Ornamental plants evaluated for susceptibility to root rot caused by Phytophthora capsici and $P$. tropicalis

\begin{tabular}{|c|c|c|c|}
\hline \multicolumn{2}{|l|}{ Host } & \multirow[b]{2}{*}{$N^{\mathbf{q}}$} & \multirow[b]{2}{*}{ Experiment } \\
\hline $\begin{array}{l}\text { Family, species } \\
\text { (common name) }\end{array}$ & Cultivar & & \\
\hline \multicolumn{4}{|l|}{ Cucurbitaceae } \\
\hline $\begin{array}{l}\text { Cucurbita pepo (straightneck } \\
\text { squash) }\end{array}$ & Cougar & 12 & 1 \\
\hline \multicolumn{4}{|l|}{ Fabaceae } \\
\hline Lathyrus latifolius (sweet pea) ${ }^{\mathrm{s}}$ & Latifolia Mixed $^{\mathrm{t}}$ & 12 & 1 \\
\hline Lupinus polyphyllus (lupine) ${ }^{\mathrm{s}}$ & Gallery Pink ${ }^{\mathrm{t}}$ & $10^{\mathrm{u}}$ & 1 \\
\hline \multicolumn{4}{|l|}{ Solanaceae } \\
\hline $\begin{array}{l}\text { Browallia speciosa (bush } \\
\text { violet) })^{\mathrm{s}}\end{array}$ & Bells Silver ${ }^{t}$ & 12 & 1 \\
\hline \multirow[t]{7}{*}{$\begin{array}{l}\text { Calibrachoa } \times \text { hybrid } \\
\quad(\text { million bells })^{\mathrm{v}}\end{array}$} & $\begin{array}{l}\text { Callie Gold with } \\
\text { Red Eye }{ }^{r, w}\end{array}$ & 8 & 1,2 \\
\hline & Starlette Sunset ${ }^{\mathrm{w}, \mathrm{x}}$ & 12 & 1 \\
\hline & Cabaret Yellow ${ }^{\mathrm{w}, \mathrm{x}}$ & 12 & 2 \\
\hline & Can-Can Apricot ${ }^{\mathrm{w}, \mathrm{x}}$ & 12 & 2 \\
\hline & $\begin{array}{l}\text { Celebration } \\
\text { Purple Star }\end{array}$ & 12 & 2 \\
\hline & $\begin{array}{l}\text { Million Bells } \\
\text { Cherry Pink }^{\mathrm{w}, \mathrm{x}}\end{array}$ & 12 & 2 \\
\hline & Superbells White ${ }^{\mathrm{x}, \mathrm{z}}$ & 12 & 2 \\
\hline $\begin{array}{l}\text { Nicotiana } \times \text { sanderae } \\
\quad(\text { flowering tobacco })^{\mathrm{s}}\end{array}$ & Perfume Deep Purple ${ }^{t}$ & 12 & 1 \\
\hline $\begin{array}{l}\text { Nierembergia scoparia (cup } \\
\text { flower) }{ }^{\mathrm{s}}\end{array}$ & Purple Robe & 12 & 1 \\
\hline Petunia $\times$ hybrida (petunia) $^{\mathrm{s}}$ & Prism Sunshine ${ }^{t}$ & 12 & 1 \\
\hline
\end{tabular}

q Number of replicates.

${ }^{\mathrm{r}}$ Rispens Seeds, CA.

s Received as rooted cuttings or seedlings from C. Raker \& Sons, MI.

${ }^{t}$ Used in experiment 1 only.

u In all, 10 replicates were evaluated in runs 1 and 2 and 12 replicates were evaluated in run 3; for the second experiment 12 replicates were evaluated for runs 1 and 2 .

$v$ Run 3 did not include million bells due to the inability to acquire the same cultivars from commercial producers that were used in runs 1 and 2 .

w Received as rooted cuttings from Sunbelt Greenhouse, GA.

${ }^{x}$ Used in experiment 2 only.

y Received as rooted cuttings from Mast Young Plants, MI.

${ }^{\mathrm{z}}$ Received as rooted cuttings from Four Star Greenhouse, MI 
and 12 days after transplanting at the rate of $124.9 \mathrm{ml} /$ liter for prevention of black root rot (Thielaviopsis basicola). Greenhouse temperature and relative humidity were recorded hourly with a Watchdog data logger (450 series; Spectrum Technologies, Inc., East Plainfield, IL) and to calculate mean air temperature and relative humidity.

Inoculum was prepared according to the methods of QuesadaOcampo et al. (2009). For runs 1 and 2, infested millet seed (approximately $1 \mathrm{~g}$ ) were placed on the surface of potting media near plant stems for the experiment with fabaceous and solanaceous plants. At $14 \mathrm{dpi}$, approximately $0.5 \mathrm{~g}$ of infested millet seed were added to the potting media to ensure adequate disease development. For the Calibrachoa cultivar experiment and for run 3 of the experiment with fabaceous and solanaceous plants, millet seed were buried to a depth of 2 to $3 \mathrm{~cm}$ and about $1 \mathrm{~cm}$ away from the crown to prevent inoculum desiccation. Control plants were inoculated with sterile millet seed. Plants were watered after inoculation to prevent inoculum desiccation.

For both experiments, plants were assessed for disease symptoms at 2-day intervals from 0 to $42 \mathrm{dpi}$. Plant height and mean canopy width (calculated by averaging two width measurements [the second measurement perpendicular to the first]) of each replicate were measured (in centimeters) at 7-day intervals from 14 to $42 \mathrm{dpi}$ in experiment 1 and from 0 to $42 \mathrm{dpi}$ in experiment 2 . Crown and root tissue of $50 \%$ of inoculated plants were excised upon death or experiment completion. Asymptomatic control plants were also sampled. Excess roots and foliage were removed, and plants were gently rinsed with water to remove remaining potting media. Plants were surface disinfested in a $5 \%$ bleach solution $(0.31 \%$ sodium hypochlorite) for $3 \mathrm{~min}$, submerged in distilled water for $1 \mathrm{~min}$, and air dried. Squash plants were surface disinfested with $70 \%$ ethanol and air dried. Two sections of tissue were excised from the crown and roots and plated on BARP-amended UCV8 agar. Cultures were observed 3 days after plating using a compound microscope at $\times 100$ magnification and confirmed as $P$. capsici based on morphological characteristics according to Waterhouse (1963). P. tropicalis was confirmed according to Aragaki and Uchida (2001). Isolates were characterized for CT and MS as previously described (Lamour and Hausbeck 2000), and the phenotype of recovered isolates was compared with the original inoculum.

Statistical analyses. Plant height and mean canopy width were used to calculate plant volume (volume of a cylinder $\left[V=\pi r^{2} h\right]$ ) to standardize height and canopy width measurements among plants. Mean plant volume (in cubic centimeters) of each plant type was determined by averaging the volume of the plant type-pathogen isolate pairing at every interval. Mean plant volume data were analyzed by analysis of variance (ANOVA) using the PROC MIXED procedure of SAS (version 9.2; SAS Institute Inc., Cary, NC). Repeated-measures analyses were conducted by applying the REPEATED statement with autoregressive of order 1 with heterogeneous variance-covariance structure (with the lowest Akaike's Information Criterion (AIC) and Bayesian Information Criterion (BIC) values chosen) to make conclusions on mean plant volume. Variances were tested for heterogeneity using Levene's test and, when necessary, the GROUP option of the REPEATED statement (with the lowest AIC value = plant type $\times$ pathogen isolate) was used, with degrees of freedom calculated according to KenwardRoger. Plant replicate volume calculations of each plant type-pathogen isolate pairing for each 7-day interval were placed into the area under the disease progress curve mathematical formula according to Shaner and Finney (1977) to assess stunting or death over time, and are referred to hereafter as area under the plant growth curve (AUPGC). Larger AUPGC values signify greater plant volume. AUPGC values were analyzed by ANOVA using the PROC MIXED procedure of SAS (version 9.2). If ANOVA was significant for mean plant volume or AUPGC value main effects or interaction terms, treatment means were compared using Fisher's protected least significant difference at $P=0.05$. Estimates and + estimate standard errors were back transformed to report least square means and standard errors.

\section{Results}

Pathogenicity on fabaceous and solanaceous plants. Disease incidence varied among plant type-pathogen isolate pairings; some plants appeared healthy, while others became severely diseased (Table 2). Recovered P. capsici or P. tropicalis isolates from all plants were confirmed to have the same phenotype as the original inoculum (data not shown). Control seedlings did not exhibit disease symptoms, nor were the pathogens recovered (data not shown).

Mean air temperature and relative humidity for the experiment with fabaceous and solanaceous plants were $21.1^{\circ} \mathrm{C}\left( \pm 17.3^{\circ} \mathrm{C}\right)$ and $55.5 \%( \pm 39.7 \%)$, respectively. Mean plant volume data were square root transformed prior to analyses to satisfy normality assumptions and variances were heterogeneous for plant type and pathogen isolate. Because the Calibrachoa cultivars were not included in run 3, statistical differences were detected among experimental runs. Statistical differences were not found among runs when Calibrachoa cultivars were removed from run 1 and 2 data sets. Plant type $(P<0.0001)$, pathogen isolate $(P<0.0001)$, dpi $(P<0.0001)$, and the interaction $(P<0.0001)$ were significant for mean plant volume. The interaction between plant type and pathogen isolate was significant, except for the squash plants inoculated with $P$. capsici isolates SP98 $(P=0.4051), 12889$ $(P=0.1435)$, and $13351(P=0.4121)$. Plant type $(P<0.0001)$, pathogen isolate $(P<0.0001)$, and the interaction $(P<0.0001)$ were significant for plant AUPGC values. Nicotiana spp. $(P=0.0395)$, 'Callie Gold with Red Eye' $(P=0.0013)$ and 'Starlette Sunset' Calibrachoa

Table 2. Disease incidence of and pathogen recovery from ornamental plants evaluated for susceptibility to Phytophthora capsici isolates OP97, SP98, 12889, and 13351 and $P$. tropicalis isolate 13715

\begin{tabular}{|c|c|c|c|c|c|c|c|c|c|c|}
\hline \multirow[b]{4}{*}{ Plant } & \multicolumn{10}{|c|}{ Disease incidence and pathogen recovery $(\%)^{y}$} \\
\hline & \multicolumn{8}{|c|}{$P$. capsici isolates } & \multirow{2}{*}{\multicolumn{2}{|c|}{$\begin{array}{c}\text { P. tropicalis } \\
13715\end{array}$}} \\
\hline & \multicolumn{2}{|c|}{ OP97 } & \multicolumn{2}{|c|}{ SP98 } & \multicolumn{2}{|c|}{12889} & \multicolumn{2}{|c|}{13351} & & \\
\hline & DI & PR & DI & PR & DI & $\mathbf{P R}$ & DI & PR & DI & $\overline{\mathbf{P R}}$ \\
\hline Browallia speciosa & 0.0 & 0.0 & 0.0 & 0.0 & 0.0 & 0.0 & 0.0 & 0.0 & 0.0 & 0.0 \\
\hline Nierembergia scoparia & 0.0 & 0.0 & 0.0 & 0.0 & 0.0 & 0.0 & 0.0 & 0.0 & 0.0 & 0.0 \\
\hline Nicotiana $\times$ sanderae & 16.7 & 8.9 & 11.1 & 2.2 & 38.9 & 16.7 & 22.2 & 5.6 & 41.7 & 44.4 \\
\hline Lupinus polyphyllus & 78.1 & 3.8 & 43.7 & 62.5 & 65.6 & 50.0 & 71.9 & 75.0 & 81.3 & 57.8 \\
\hline \multicolumn{11}{|l|}{ Calibrachoa $\times$ hybrida } \\
\hline 'Callie Gold with Red Eye' & 6.3 & 12.5 & 25.0 & 25.0 & 6.3 & 0.0 & 6.3 & 37.5 & 100.0 & 100.0 \\
\hline 'Starlette Sunset' & 25.0 & 0.0 & 12.5 & 25.0 & 20.8 & 0.0 & 16.7 & 33.3 & 100.0 & 100.0 \\
\hline Petunia $\times$ hybrida & 0.0 & 5.6 & 0.0 & 5.6 & 0.0 & 5.6 & 0.0 & 11.1 & 0.0 & 0.0 \\
\hline Cucurbita pepo & 100.0 & 100.0 & 100.0 & 100.0 & 100.0 & 100.0 & 100.0 & 100.0 & 86.0 & 75.0 \\
\hline Lathyrus latifolius & 5.6 & 5.6 & 8.3 & 0.0 & 5.6 & 0.0 & 8.3 & 5.6 & 16.7 & 22.2 \\
\hline
\end{tabular}

y Disease incidence (DI) was calculated for plants inoculated with each isolate by dividing the number of plants that exhibited root rot symptoms by the total number of plants inoculated with each isolate and multiplying by 100. Pathogen recovery (PR) was calculated for plants inoculated with each isolate by the percentage of confirmed $P$. capsici or $P$. tropicalis isolates recovered from root or crown tissue of $50 \%$ of each plant type inoculated with each isolate and control plants. Control plants did not exhibit disease symptoms, nor were $P$. capsici or $P$. tropicalis recovered.

${ }^{z}$ Calibrachoa cultivars were evaluated in runs 1 and 2 only. 
$(P<0.0001)$, squash $(P<0.0001)$, and all pathogen isolates $(P<$ 0.0001 ) were significant for AUPGC when the interaction term was sliced by plant type and pathogen isolate.

Disease onset for Nicotiana spp. and L. polyphyllus inoculated with P. capsici or P. tropicalis occurred within 17 and 19 dpi, respectively. Symptoms included stunting, wilting, and chlorotic foliage that became necrotic, with occasional plant death (Fig. 1A to C). Roots of symptomatic Nicotiana spp. and L. polyphyllus ranged from slightly rotted to brown and decayed. Pathogen recovery from the host tissue ranged from 3.8 to $75.0 \%$ among isolates (Table 2). Nicotiana spp. inoculated with $P$. capsici isolates 12889 or 13351 or $P$. tropicalis were stunted compared with control plants 35 dpi (data not shown) but were similar in size 42 dpi (Fig. 2A). Nicotiana spp. inoculated with $P$. capsici isolates OP97 or 12889 or $P$. tropicalis had lower AUPGC values (414255, 358275, and 372571, respectively) than control plants (492544) (Fig. 2B). L. polyphyllus plants inoculated with $P$. capsici or $P$. tropicalis were similar in size $42 \mathrm{dpi}$ and had AUPGC values similar to the control plants (Fig. 2).

Both cultivars of Calibrachoa included in this experiment became diseased when inoculated with $P$. tropicalis. Symptoms included necrotic crown lesions that progressed to the stems 12 dpi. Asymmetrical foliar wilting generally followed. Older foliage closest to the base wilted first (Fig. 1D), with all aboveground tissues eventually losing turgidity, resulting in plant death (Fig. 1E). Roots of diseased plants were brown and decayed. Disease incidence among Calibrachoa cultivar-P. capsici isolate pairings ranged from 6.3 to $25.0 \%$, with pathogen recovery varying among cultivars and isolates (Table 2). Symptomatic plants resembled those infected by $P$. tropicalis. Callie Gold with Red Eye and Starlette Sunset Calibrachoa inoculated with $P$. tropicalis were smaller than $P$. capsici-inoculated and control plants at 42 dpi (Fig. 2A). Callie Gold with Red Eye and Starlette Sunset Calibrachoa inoculated with $P$. tropicalis had lower AUPGC values (AUPGC values $=36,337$ and 95,302, respectively) than P. capsici-inoculated and control plants (AUPGC values $=207,116$ and 308,890, respectively) (Fig. 2B).

Squash inoculated with $P$. tropicalis exhibited disease symptoms 7 dpi. Plants developed water-soaked crown lesions that progressed to the stems but did not extend beyond cotyledons. Over time, lesions hardened and ceased to enlarge (Fig. 1F and G). First and second true leaves lost turgidity; however, seedlings did not collapse. Squash inoculated with $P$. capsici began to exhibit wilting and crown lesions at $5 \mathrm{dpi}$; seedlings then collapsed and died. Disease incidence and pathogen recovery among squash-P. capsici isolate pairings was $100 \%$; disease incidence and pathogen recovery of $P$. tropicalis-inoculated squash was 86.0 and $75.0 \%$, respectively (Table 2). Squash plants inoculated with $P$. tropicalis were similar in size to control plants at 42 dpi (Fig. 2A). The AUPGC values of $P$. tropicalis-inoculated and control squash plants were similar (Fig. 2B). Squash inoculated with $P$. capsici isolates had lower AUPGC values than P. tropicalis-inoculated and control plants (Fig. 2B).

Lathyrus latifolius became diseased when inoculated with either P. capsici or P. tropicalis (Table 2). Foliar chlorosis was observed

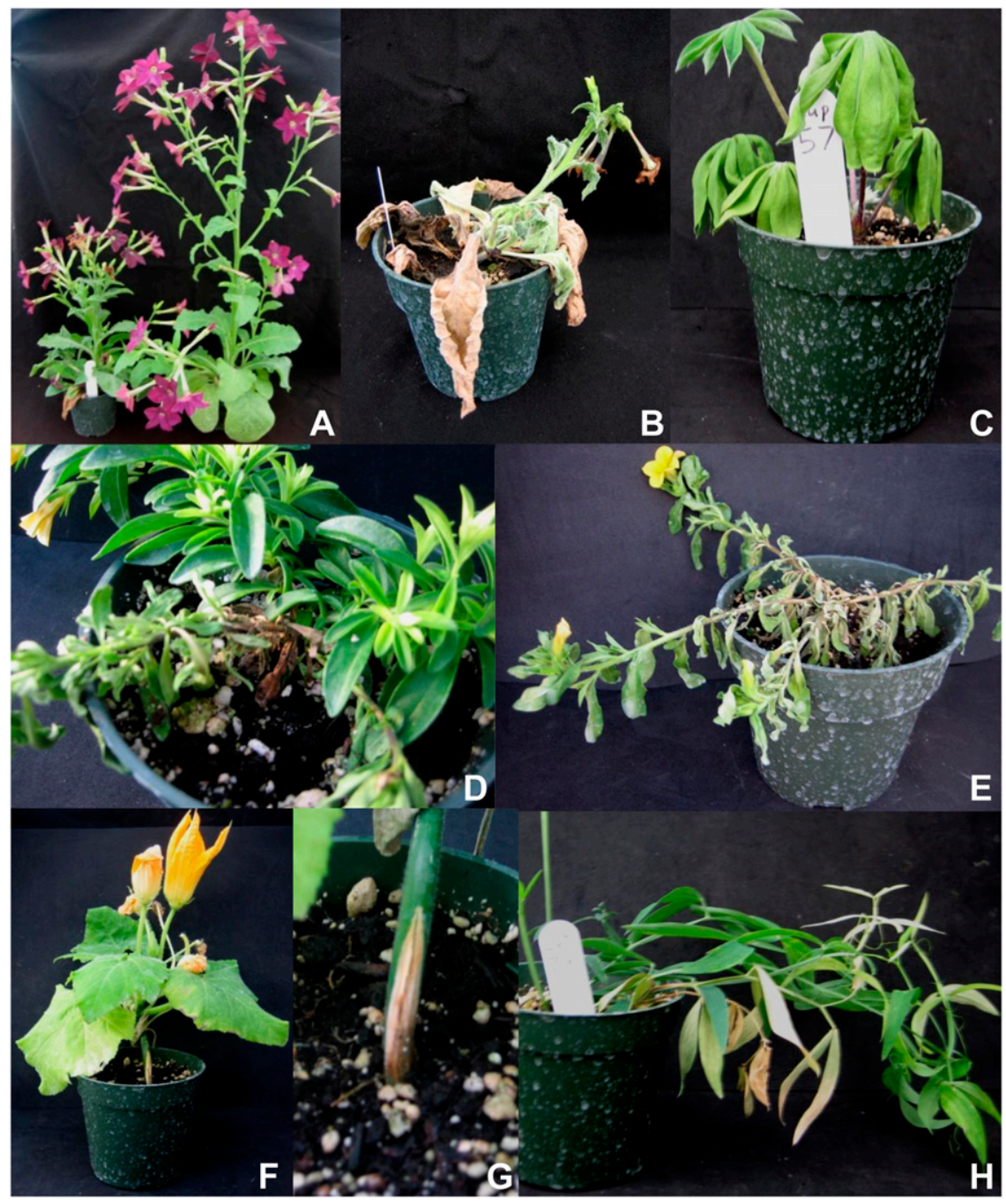

Fig. 1. Aboveground root rot symptoms caused by Phytophthora capsici or P. tropicalis. A, Stunting and B, death of Nicotiana $\times$ sanderae. C, Foliar and stem wilting of Lupinus polyphyllus. D, Asymmetrical foliar wilting and $\mathbf{E}$, death of Calibrachoa $\times$ hybrida. F and $\mathbf{G}$, Crown lesions on straightneck squash. $\mathbf{H}$, Chlorotic and necrotic foliage of Lathyrus latifolius. 
26 dpi (Fig. 1H); necrosis developed soon thereafter. Symptomatic plants were not vigorous, and roots ranged from healthy appearing to brown and decayed. Pathogen recovery varied among isolates (Table 2). Inoculated plants were similar in size and AUPGC values to control plants 42 dpi (Fig. 2).

Petunia plants inoculated with $P$. capsici remained asymptomatic but the pathogen was recovered (Table 2). Petunia plants inoculated with $P$. tropicalis displayed no symptoms, and the pathogen was not recovered. Browallia speciosa and Nierembergia scoparia inoculated with $P$. capsici or $P$. tropicalis also remained asymptomatic; neither pathogen was recovered (Table 2).

Susceptibility to Phytophthora spp. among Calibrachoa cultivars. Disease incidence and pathogen recovery from $P$. tropicalis-inoculated cultivars was $100 \%$. Disease incidence and pathogen recovery varied among $P$. capsici-inoculated cultivars and ranged from 75.0 to $92.0 \%$ and 16.7 to $100.0 \%$, respectively (Table 3). AUPGC values of the Calibrachoa cultivar experiment were square root transformed prior to analyses to satisfy normality assumptions. Variances were heterogeneous for plant type and pathogen isolate. There were no significant differences among experiments and data were combined. For the Calibrachoa cultivar experiment, mean air temperature and relative humidity were $23.4^{\circ} \mathrm{C}\left( \pm 12.5^{\circ} \mathrm{C}\right)$ and $30.5 \%( \pm 26.6 \%)$, respectively.

Cultivar, pathogen isolate, dpi, and the interaction were significant $(P<0.0001)$ for mean plant volume. All interactions between pathogen isolate and dpi were significant, except for $P$. capsici at $21(P=0.0489)$ and $42(P=0.3410)$ dpi. All interactions between cultivar and pathogen isolate were significant $(P<0.0001)$. Interactions among plant volume and date in 'Can-Can Apricot', 'Cabaret Yellow', Callie Gold with Red Eye, 'Million Bells Cherry Pink', and 'Superbells White' were significant. Cultivar, pathogen, and the interaction $(P=0.0004)$ were significant for AUPGC. All cultivar and pathogen isolate interactions were significant when sliced by cultivar and pathogen isolate, except for 'Celebration Purple Star' $(P=0.7713)$.

Can-Can Apricot P. capsici-inoculated and control plants were larger than $P$. tropicalis-inoculated plants $14 \mathrm{dpi}$ (data not shown). At 42 dpi, Callie Gold with Red Eye and Million Bells Cherry Pink P. capsici-inoculated and control plants were larger than P. tropicalisinoculated plants (Fig. 3A). When Cabaret Yellow and Can-Can Apricot were inoculated with $P$. capsici, they were smaller than control plants at 42 dpi (Fig. 3A). Superbells White $P$. tropicalis-inoculated plants were smaller than $P$. capsici-inoculated and control plants at 42 dpi (Fig. 3A). Celebration Purple Star P. capsici- or P. tropicalisinoculated and control plants were similar in size throughout the experiment.

Million Bells Cherry Pink control plants had the highest AUPGC value (AUPGC value $=2,242$ ) compared with the control plants of all other cultivars and also had the highest AUPGC value (AUPGC value $=1,830$ ) when inoculated with $P$. capsici (Fig. 3B). $P$. capsiciinoculated and control Callie Gold with Red Eye, Celebration Purple Star, Million Bells Cherry Pink, and Superbells White plants had similar AUPGC values (Fig. 3B). Cabaret Yellow had the lowest AUPGC value (AUPGC value $=1,178$ ) following inoculation with $P$. capsici (Fig. 3B). Celebration Purple Star had the highest AUPGC value (AUPGC value $=1,266$ ) of $P$. tropicalis-inoculated plants (Fig. $3 B$ ).
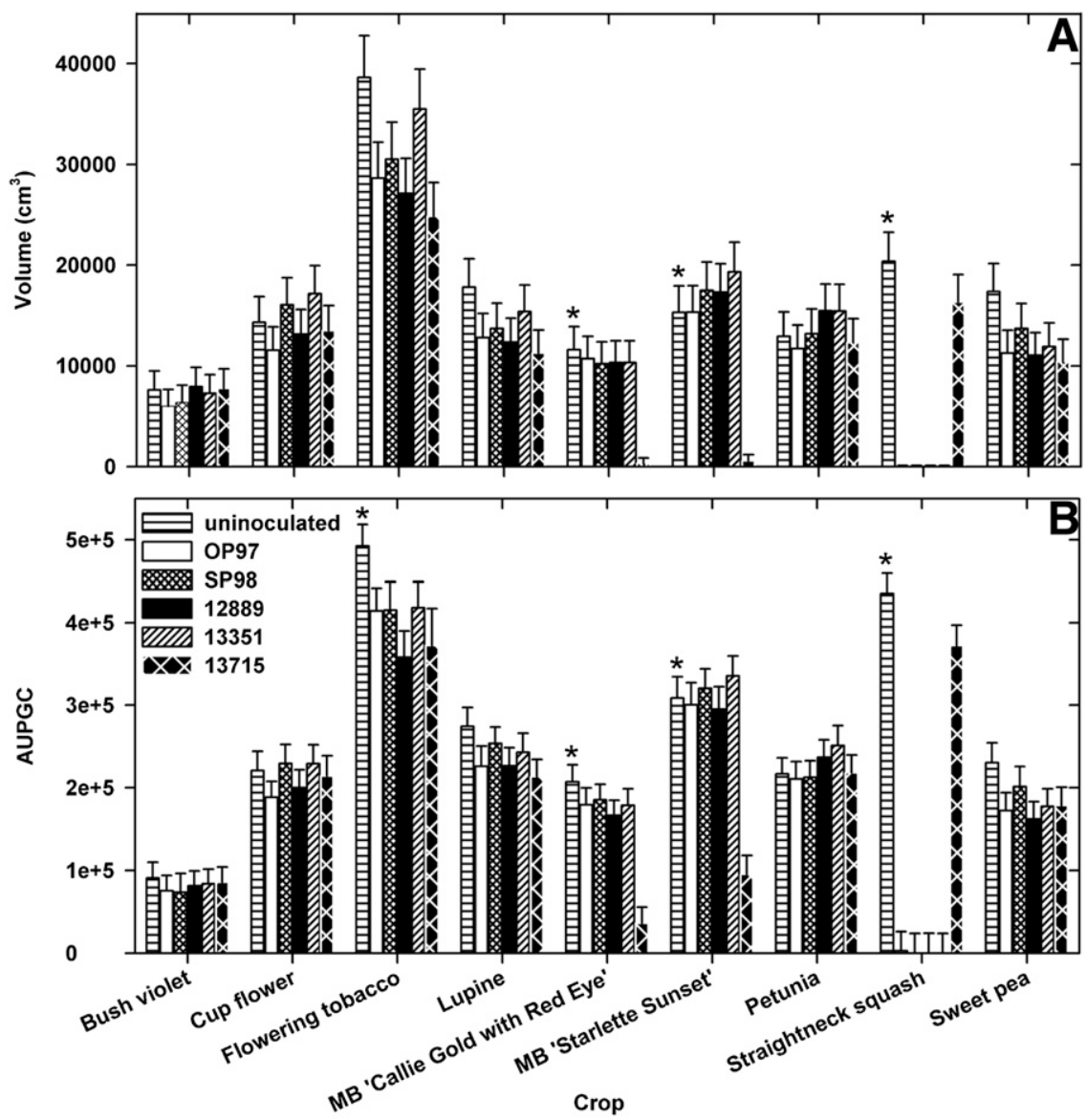

Fig. 2. A, Mean plant volume (in cubic centimeters) of fabaceous and solanaceous ornamental plants 42 days postinoculation evaluated for susceptibility to root rot caused by Phytophthora capsici isolates OP97, SP98, 12889, and 13351 and P. tropicalis isolate 13715. B, Area under the plant growth curve (AUPGC) values of ornamental plants evaluated for susceptibility to root rot caused by Phytophthora capsici isolates OP97, SP98, 12889, and 13351 and P. tropicalis isolate 13715. Plant height and canopy width measurements (in centimeters) taken at 7-day intervals from 14 to 42 days postinoculation were used to calculate a volume approximation (volume of a cylinder [ $\left.V=\pi r^{2} h\right]$ ) to standardize height and canopy width measurements among plants. Volume measurements (in cubic centimeters) were placed into the area under the disease progress curve formula to assess stunting or death over time. Larger AUPGC values signify greater plant volume. A and B, Bars represent + standard error. Symbols $\left(^{*}\right)$ represent significant differences among uninoculated and inoculated plants within each plant type (Fisher's protected least significant difference, $P=0.05$ ). MB represents Calibrachoa. 
AUPGC values of $P$. capsici- or $P$. tropicalis-inoculated and control Celebration Purple Star plants were similar (Fig. 3B).

\section{Discussion}

Phytophthora spp. incite root, crown, and stem rot of flowering annuals and perennials, in addition to vegetables and woody perennials (Aragaki and Uchida 2001; Daughtrey et al. 1995; Donahoo and Lamour 2008; Erwin and Ribeiro 1996; Gerlach and Schubert 2001; Hao et al. 2010; Hong et al. 2008; Olson and Benson 2011; Orlikowski et al. 2006; Oudemans and Coffey 1991; QuesadaOcampo et al. 2009). In our study, P. capsici was able to cause disease on ornamentals as well as straightneck squash. Lupinus polyphyllus, Calibrachoa spp., and Lathyrus latifolius are newly identified hosts for P. capsici. In addition, squash and L. latifolius are newly described susceptible hosts for $P$. tropicalis. These results clearly show that $P$. tropicalis and $P$. capsici can cause disease on both ornamentals and vegetables. Molecular methods analyzing many genes may be necessary to differentiate $P$. capsici and $P$. tropicalis isolates, because morphology (Granke et al. 2011) and host pathogenicity cannot be relied upon for accurate differentiation.

Although P. capsici could be isolated from inoculated Petunia plants, disease symptoms were not observed. Phytophthora-infected plants may appear healthy and not show disease symptoms until stress occurs via suboptimal environmental conditions (Lamour et al. 2003). These latent or asymptomatic infections can facilitate the spread of infected propagules and materials. Future experiments are necessary to discern whether plant types which remained relatively asymptomatic, similar to petunia, may harbor Phytophthora spp. and be a source of inoculum in the greenhouse. Disease was not observed on nor was either pathogen recovered from $B$. speciosa or $N$. scoparia in this study, and they are not reported hosts of any Phytophthora spp. (Farr and Rossman 2011). Pathogen recovery varied greatly among the plant types but the crowns of several species were fibrous and woody, which may have contributed to low pathogen recovery. Phytophthora spp. recovery from woody host tissue is recognized to be difficult (Quesada-Ocampo et al. 2009).

In our study, all Calibrachoa cultivars were susceptible to both $P$. capsici and $P$. tropicalis but the degree of susceptibility differed. All cultivars died when inoculated with $P$. tropicalis, with the exception of Celebration Purple Star at 42 dpi. Though Celebration Purple Star survived, it was stunted compared with the uninoculated control. Differences in cultivar response to $P$. capsici were also observed, suggesting that host resistance to $P$. capsici and $P$. tropicalis is present in existing Calibrachoa cultivars. Additional experiments to

Table 3. Disease incidence and pathogen recovery from 'Million Bells' (Calibrachoa $\times$ hybrida) cultivars evaluated for susceptibility to Phytophthora capsici and P. tropicalis

\begin{tabular}{lccccc}
\hline & \multicolumn{3}{c}{ Disease incidence and pathogen recovery } \\
\cline { 2 - 3 } & \multicolumn{2}{c}{$\boldsymbol{P .}$ capsici } & & \multicolumn{2}{c}{$\boldsymbol{P}$. tropicalis } \\
\cline { 2 - 3 } \cline { 5 - 6 } Cultivar & DI & PR & & DI & PR \\
\hline Cabaret Yellow & 75.0 & 91.7 & & 100.0 & 100.0 \\
Callie Gold with Red Eye & 62.5 & 100.0 & & 100.0 & 100.0 \\
Can-Can Apricot & 92.0 & 91.7 & & 100.0 & 100.0 \\
Celebration Purple Star & 75.0 & 25.0 & & 100.0 & 100.0 \\
Million Bells Cherry Pink & 79.2 & 91.7 & & 100.0 & 100.0 \\
Superbells White & 79.2 & 16.7 & 100.0 & 100.0 \\
\hline
\end{tabular}

${ }^{\mathrm{z}}$ Disease incidence (DI) was calculated for cultivars inoculated with each isolate.by dividing the number of plants of each cultivar that exhibited root rot symptoms by the total number of plants of each cultivar inoculated with each isolate and multiplying by 100 . Pathogen recovery (PR) was calculated for cultivars inoculated with each isolate by the percentage of confirmed $P$. capsici or $P$. tropicalis isolates recovered from root or crown tissue of $50 \%$ of plants of each cultivar inoculated with each isolate and control plants. Control plants did not exhibit disease symptoms, nor were $P$. capsici or $P$. tropicalis recovered. evaluate Calibrachoa cultivars with $P$. capsici and $P$. tropicalis may be of interest to propagators and breeders.

Squash plants and fruit are known to be very susceptible to $P$. capsici (Erwin and Ribeiro 1996; Hausbeck and Lamour 2004). In our study, squash fruit became diseased and seedlings also became minimally diseased when inoculated with $P$. tropicalis. Similarly, Hong et al. (2008) observed damping-off of cucumber seedlings following inoculation of $P$. tropicalis. Age-related resistance to $P$. capsici has been found in pumpkin (Lee et al. 2001), and further experiments could discern whether squash plants would exhibit disease if exposed to $P$. tropicalis inoculum at a later growth stage.

Integrated pest management (IPM) practices in greenhouse and nursery production are needed to mitigate the risk of pathogen infection and spread. Phytophthora spp. inocula may be introduced into greenhouse production areas via shipments of infected seed, cuttings, or plants (Daughtrey and Benson 2005; Lamour et al. 2003). If greenhouse growers incorporate field soil into the production system, the risk of introducing $P$. capsici also increases. $P$. tropicalis infections have been reported in multiple greenhouses and nurseries in the United States (Hao et al. 2010; Hong et al. 2006; Olson and Benson 2011) and Europe (Cacciola et al. 2006; Gerlach and Schubert 2001; Orlikowski et al. 2006). With the increased production of vegetable transplants for retail sale alongside ornamental plants, the prevalence of Phytophthora rot caused by P. capsici may rise in the greenhouse.

Once a pathogen is established in a facility, asexual propagules, mycelial fragments, or zoospores may be further disseminated (Lamour et al. 2003) via infested potting media that may be leached

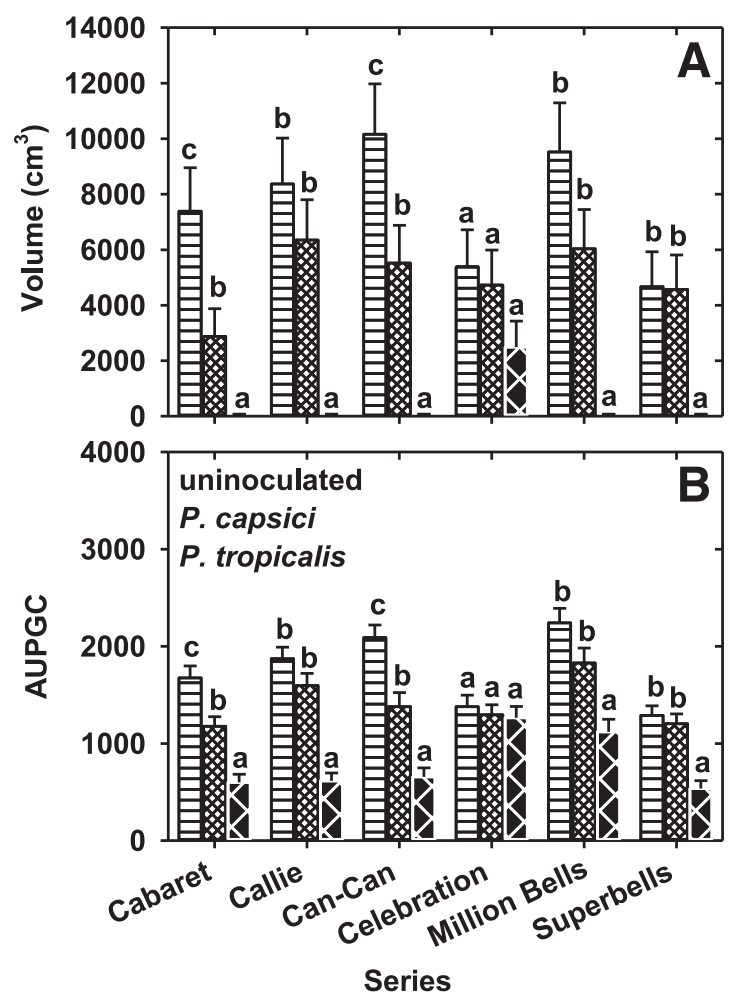

Fig. 3. A, Mean plant volume (in cubic centimeters) of Calibrachoa $\times$ hybrida series 42 days postinoculation evaluated for susceptibility to root rot caused by Phytophthora capsici and $P$. tropicalis. B, Area under the plant growth curve (AUPGC) values of Calibrachoa series evaluated for susceptibility to root rot caused by Phytophthora capsici and $P$. tropicalis. Plant height and canopy width measurements (in centimeters) taken at 7-day intervals from 0 to 42 days postinoculation were used to calculate a volume approximation (volume of a cylinder $\left[V=\pi r^{2} h\right]$ ) to standardize height and canopy width measurements among plants. Plant volume measurements were placed into the area under the disease progress curve formula to assess stunting or death over time. Larger AUPGC values signify greater plant volume. A and B, Bars represent + standard error. Bars with a letter in common are not significantly different within each series (Fisher's protected least significant difference, $P=0.05$ ). 
into irrigation water or nutrient solutions, which is reused and dispersed to other plants (Oh and Son 2008). In particular, Phytophthora-infested nutrient solutions administered through ebb-and-flow systems have been documented to cause root rot of gerbera daisy (Thinggaard and Andersen 1995; van der Gaag et al. 2001) and kalanchoe (Kalanchoe blossfeldiana) (Oh and Son 2008).

Surface water used for irrigation is frequently contaminated with Phytophthora spp. propagules, including P. tropicalis and P. capsici (Dreistadt 2001; Gevens et al. 2007; Granke and Hausbeck 2010; Hong and Moorman 2005). P. tropicalis was detected in irrigation water at a Virginia nursery during two consecutive growing seasons and was isolated from diseased garden center ornamentals (Hong et al. 2006). Contaminated water may pose a significant threat to susceptible greenhouse ornamentals and vegetables that are irrigated with surface water from nearby vegetable production fields.

In summary, the overlap of $P$. capsici- and $P$. tropicalis-susceptible hosts is increasing, and pathogen dispersal among and within production facilities is a considerable concern. The results of the study clearly demonstrate that some ornamentals may serve as symptomatic or asymptomatic hosts of $P$. capsici or $P$. tropicalis. With increased vegetable transplant production in ornamental greenhouses and asymptomatic infected ornamentals, further investigation into refining greenhouse production IPM programs to limit root rot caused by $P$. capsici and $P$. tropicalis should be conducted.

\section{Acknowledgments}

This research is based upon work supported by the Specific Cooperative Agreement number 59-1907-0-096 between the United States Department of AgricultureAgricultural Research Service Biological Integrated Pest Management Unit, Ithaca, NY, and the Michigan State University Department of Plant, Soil, and Microbial Sciences, East Lansing, MI as part of the Floriculture and Nursery Research Initiative, and the American Floral Endowment. We thank M. Daughtrey and C. Smart for providing pathogen isolates used in this research; T. Gallagher, L. Granke, B. Harlan, L. Quesada-Ocampo, L. Rodriguez-Salamanca, J. Schmidt, and A. Vargas-Berdugo for technical assistance; S. Linderman for document review; and K. Ananyeva, L. Ruan, and W. Yang for help with statistical analyses.

\section{Literature Cited}

Alizadeh, A., and Tsao, P. H. 1985. Effect of light on sporangium formation, morphology, ontogeny, and caducity of Phytophthora capsici and ' $P$. palmivora' MF4 isolates from black pepper and other hosts. Trans. Br. Mycol. Soc. 85:47-69.

Ampuero, J., Latorre, B. A., Torres, R., and Chávez, E. R. 2008. Identification of Phytophthora cryptogea as the cause of rapid decline of petunia (Petunia $\times$ hybrida) in Chile. Plant Dis. 92:1529-1536.

Aragaki, M., and Uchida, J. Y. 2001. Morphological distinctions between Phytophthora capsici and P. tropicalis sp. nov. Mycologia 93:137-145.

Babadoost, M. 2000. Outbreak of Phytophthora foliar blight and fruit rot in processing pumpkin fields in Illinois. Plant Dis. 84:1345.

Baker, K. F., and Linderman, R. G. 1979. Unique features of the pathology of ornamental plants. Annu. Rev. Phytopathol. 17:253-277.

Brasier, C. M., and Griffin, M. J. 1979. Taxonomy of Phytophthora palmivora on cocoa. Trans. Br. Mycol. Soc. 72:111-143.

Cacciola, S. O., Spica, D., Cooke, D. E. L., Raudino, F., and Maganao di San Lio, G. 2006. Wilt and collapse of Cuphea ignea caused by Phytophthora tropicalis in Italy. Plant Dis. 90:680.

Daughtrey, M. L., and Tobiasz, M. 2008. Fungicidal control of Phytophthora root and crown rot on calibrachoa, 2007. Plant Dis. Manag. Rep. 2:OT014.

Daughtrey, M. L., and Benson, D. M. 2005. Principles of plant heath management for ornamental plants. Annu. Rev. Phytopathol. 43:141-169.

Daughtrey, M. L., Wick, R. L., and Peterson, J. L. 1995. Compendium of Flowering Plant Diseases. American Phytopathological Society, St. Paul, MN.

Davidson, C. R., Carroll, R. B., Evans, T. A., and Mulrooney, R. P. 2002. First report of Phytophthora capsici infecting lima bean (Phaseolus lunatus) in the Mid-Atlantic region. Plant Dis. 86:1049.

Donahoo, R. S., and Lamour, K. H. 2008. Interspecific hybridization and apomixes between Phytophthora capsici and Phytophthora tropicalis. Mycologia 100: 911-920.

Dreistadt, S. H. 2001. Integrated Pest Management for Floriculture and Nurseries: University of California Statewide Integrated Pest Management Project, Division of Agriculture and Natural Resources, Publ. 3402. Regents of the University of California, Division of Agriculture and Natural Resources, Davis, CA.

Enzenbacher, T. B., and Hausbeck, M. K. 2012. An evaluation of cucurbits for susceptibility to cucurbitaceous and solanaceous Phytophthora capsici isolates. Plant Dis. 96:1404-1414.

Erwin, D. C., and Ribeiro, O. K. 1996. Phytophthora Diseases Worldwide. American Phytopathological Society, St. Paul, MN.
Farr, D. F., and Rossman, A. Y. 2011. Fungal Databases, Systematic Mycology and Microbiology Laboratory, ARS, USDA. Online publication. http://nt.arsgrin.gov/fungaldatabases/

Foster, J. M., and Hausbeck, M. K. 2010. Resistance of pepper to Phytophthora crown, root, and fruit rot is affected by isolate virulence. Plant Dis. 94:24-30.

Foster, J. M., Naegele, R. P., and Hausbeck, M. K. 2013. Evaluation of eggplant rootstocks and pepper varieties for potential resistance to isolates of Phytophthora capsici from Michigan and New York. Plant Dis. 97: 1037-1041.

Gerlach, W. W. P., and Schubert, R. 2001. A new wilt of Cyclamen caused by Phytophthora tropicalis in Germany and the Netherlands. Plant Dis. 85:334.

Gevens, A. J., Donahoo, R. S., Lamour, K. H., and Hausbeck, M. K. 2007. Characterization of Phytophthora capsici from Michigan surface irrigation water. Phytopathology 97:421-428.

Gevens, A. J., Donahoo, R. S., Lamour, K. H., and Hausbeck, M. K. 2008 Characterization of Phytophthora capsici causing foliar and pod blight of snap bean in Michigan. Plant Dis. 92:201-209.

Granke, L. L., and Hausbeck, M. K. 2010. Effects of temperature, concentration, age, and algaecides on Phytophthora capsici zoospore infectivity. Plant Dis. 94:54-60.

Granke, L. L., Quesada-Ocampo, L. M., and Hausbeck, M. K. 2011. Variation in phenotypic characteristics of Phytophthora capsici isolates from a worldwide collection. Plant Dis. 95:1080-1088.

Hao, W., Richardson, P. A., and Hong, C. X. 2010. Foliar blight of annual vinca (Catharanthus roseus) caused by Phytophthora tropicalis in Virginia. Plant Dis. 94:274.

Hausbeck, M. K., and Lamour, K. H. 2004. Phytophthora capsici on vegetable crops: Research progress and management challenges. Plant Dis. 88:1292-1303.

Hong, C., Richardson, P. A., and Kong, P. 2008. Pathogenicity to ornamental plants of some existing species and new taxa of Phytophthora from irrigation water. Plant Dis. 92:1201-1207.

Hong, C. X., and Moorman, G. W. 2005. Plant pathogens in irrigation water: Challenges and opportunities. Crit. Rev. Plant Sci. 24:189-208.

Hong, C. X., Richardson, P. A., Kong, P., Jeffers, S. N., and Oak, S. W. 2006 Phytophthora tropicalis isolated from diseased leaves of Pieris japonica and Rhododendron catawbiense and found in irrigation water and soil in Virginia. Plant Dis. 90:525

Hwang, B. K., and Kim, C. H. 1995. Phytophthora blight of pepper and its control in Korea. Plant Dis. 79:221-227.

Isakeit, T. 2007. Phytophthora blight caused by Phytophthora capsici on pumpkin and winter squash in Texas. Plant Dis. 91:633

Lamour, K. 2009. Phytophthora capsici: Sex, selection, and the wealth of variation. Pages 165-178 in: Oomycete Genetics and Genomics: Diversity, Interactions, and Research Tools. K. Lamour and S. Kamoun, eds. John Wiley \& Son, Inc., Hoboken, NJ.

Lamour, K. H., Daughtrey, M. L., Benson, D. M., Hwang, J., and Hausbeck, M. K. 2003. Etiology of Phytophthora drechsleri and P. nicotianae (= P. parasitica) diseases affecting floriculture crops. Plant Dis. 87:854-858.

Lamour, K. H., and Hausbeck, M. K. 2000. Mefenoxam insensitivity and the sexual stage of Phytophthora capsici in Michigan cucurbit fields. Phytopathology 90:396-400.

Lee, B. K., Kim, B. S., Chang, S. W., and Hwang, B. K. 2001. Aggressiveness to pumpkin cultivars of isolates of Phytophthora capsici from pumpkin and pepper. Plant Dis. 85:497-500.

Leonian, L. H. 1922. Stem and fruit blight of peppers caused by Phytophthora capsici sp. nov. Phytopathology 12:401-408.

Mathis, W. L., Williams-Woodward, J., and Csinos, A. S. 1999. Insensitivity of Phytophthora capsici to mefenoxam in Georgia. (Abstr.) Phytopathology 89: S49.

Oh, M., and Son, J. E. 2008. Phytophthora nicotianae transmission and growth of potted kalanchoe in two recirculating subirrigation systems. Sci. Hortic. 119 $75-78$

Olson, H. A., and Benson, D. M. 2011. Characterization of Phytophthora spp. on floriculture crops in North Carolina. Plant Dis. 95:1013-1020.

Omer, M., Locke, J. C., Frantz, J. M., Horst, L. E., and Krause, C. R. 2011 Interaction of Calibrachoa and selected root and foliar pathogens in greenhouse settings. Acta Hortic. 893:1301-1307.

Orlikowski, L. B., Trzewik, A., Wiejacha, K., and Szkuta, G. 2006. Phytophthora tropicalis, a new pathogen of ornamental plants in Poland. J. Plant Prot. Res. 46 103-109.

Oudemans, P., and Coffey, M. D. 1991. A revised systematics of twelve papillate Phytophthora species based on isozyme analysis. Mycol. Res. 95:1025-1046.

Ploetz, R. C., and Haynes, J. L. 2000. How does Phytophthora capsici survive in squash fields in southeastern Florida during the off-season? Proc. Fla. State Hortic. Soc. 113:211-215.

Quesada-Ocampo, L. M., Fulbright, D. W., and Hausbeck, M. K. 2009 Susceptibility of Fraser fir to Phytophthora capsici. Plant Dis. 93:135-141.

Quesada-Ocampo, L. M., Granke, L. L., Mercier, M. R., Olsen, J., and Hausbeck, M. K. 2011. Investigating the genetic structure of Phytophthora capsici populations. Phytopathology 101:1061-1073.

Quesada-Ocampo, L. M., and Hausbeck, M. K. 2010. Resistance in tomato and wild relatives to crown and root rot caused by Phytophthora capsici. Phytopathology 100:619-627. 
Ristaino, J. B., and Johnston, S. A. 1999. Ecologically based approaches to management of Phytophthora blight on bell pepper. Plant Dis. 83:1080-1088. Schultz Nelson, J. 2008. Calibrachoa. Plant Palette. University of Illinois Extension. Online publication. http://web.extension.illinois.edu/dmp/palette/080518.html

Shaner, G., and Finney, R. E. 1977. The effect of nitrogen fertilization on the expression of slow-mildewing resistance in Knox wheat. Phytopathology 67: 1051-1056.

Silvar, C., Merino, F., and Diaz, J. 2006. Diversity of Phytophthora capsici in northwest Spain: Analysis of virulence, metalaxyl response, and molecular characterization. Plant Dis. 90:1135-1142

Thinggaard, K., and Andersen, H. 1995. Influence of watering frequency and electrical conductivity of the nutrient solution on Phytophthora root rot in pot plants of Gerbera. Plant Dis. 79:259-263.

Uchida, J. Y., and Aragaki, M. 1980. Chemical stimulation of oospore formation in Phytophthora capsici. Mycologia 72:1103-1107.
United States Department of Agriculture, National Agriculture Statistics Service. 2014. Floriculture Crops 2013 Summary. Table. Number of Producers by Gross Value of Sales and Expanded Wholesale Value - 15 Program States: 2012 and 2013. Online publication. http://usda.mannlib.cornell.edu/usda/ nass/FlorCrop//2010s/2014/FlorCrop-06-19-2014.pdf.

van der Gaag, D. J., Kerssies, A., and Lanser, C. 2001. Spread of Phytophthora root and crown rot in Saintpaulia, Gerbera, and Spathiphyllum pot plants in ebb-and-flow-systems. Eur. J. Plant Pathol. 107:535-542.

Waterhouse, G. M. 1963. Key to the Species of Phytophthora de Bary. The Commonwealth Mycological Society, Kew, Surrey, UK.

Wick, R. L., and Dicklow, M. B. 2002. Epipremnum, a new host for Phytophthora capsici. Plant Dis. 86:1050.

Zhang, Z. G., Zhang, J. Y., Zheng, X. B., Yang, Y. W., and Ko, W. H. 2004. Molecular distinctions between Phytophthora capsici and Ph. tropicalis on ITS sequences of ribosomal DNA. J. Phytopathol. 152:358-364. 